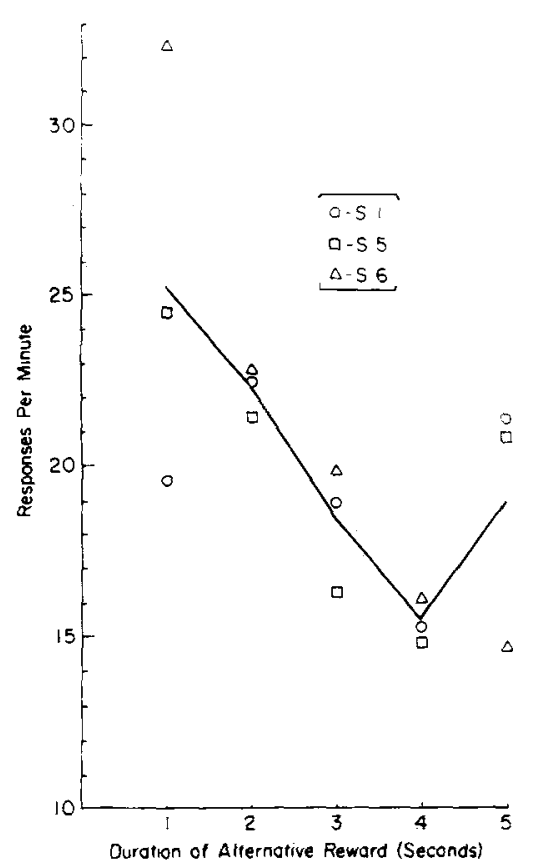

Fig. 2. The mean rate of response at the door that delivered 3 -sec reinforcers, plotted against the duration of the reinforcers (rewards) produced by responses at the alternative door.

The mean response rates and durations for the last three sessions with a particular pair of reinforcer durations was used to represent performance for that test. Every pair of reinforcer durations was tested twice, and the scores obtained on these two tests were averaged for each rat. Figure 1 shows the rate of response at the door which delivered $1-\mathrm{sec}$ reinforcers as a function of the duration of reinforcers obtained by responses at the other door. The rate of response on the door giving a $1-\mathrm{sec}$ access to the sucrose solution decreased as the duration of the alternative reinforcer increased from 1 to 5 sec.

Similar data for the three rats that always obtained 3-sec reinforcers at one of the magazines is presented in Fig. 2. The absolute rate of the response reinforced with a constant reinforcer duration appears to be related to the relative duration of its reinforcers. The relationship broke down when the alternative reinforcer was $5 \mathrm{sec}$, but the reason for this is not clear. Figure 2 shows, however, that the rate of response for a $3 \cdot \mathrm{sec}$ reinforcer decreased systematically as the duration of the alternative reinforcer ranged from 2 to $4 \mathrm{sec}$. There was no overlap between scores at the three points in the 2- to 4-sec range.

The average response rate on each manipulandum and the relative rate at the door producing a constant reinforcer duration are given in Table 2 . The relative rate (the rate at "constant" door divided by the sum of both absolute response rates) did not closely match the relative duration of the "constant" reinforcer, especially in the case of the 3 -sec constant reinforcer. Response-duration data did not show orderly changes, and thus the comparatively low response rates produced by long reinforcer durations could not be attributed to the animals taking more time to make individual responses. It seems more likely that the lack of matching was due to the brief experience allowed with each pair of reinforcer values.

In general, the absolute rate of a response that produced reinforcers of constant duration was found to vary inversely with the duration of reinforcers delivered by an alternative manipulandum. This result is similar to that obtained with pigeons by Rachlin \& Baum (1969). However, the data in Table 2 show that the sum of both response rates was inversely related to the sum of the two reinforcer durations being used. This suggests a satiation factor, or general rate-suppressing effect of increasing reinforcer amount. Rachlin \& Baum (1969) noted that their pigeons weighed about $10 \mathrm{~g}$ more after a session with the longest (16-sec) value than with the shortest $(1-\mathrm{sec})$ value of the varied reinforcer, and thus satiation effects may have contributed to the variations in rate of key pecking which they reported. This type of satiation factor needs to be more stringently controlled before the effects of reinforcer duration on rate of response and choice behavior can be properly evaluated. REFERENCES

CATANIA, A. C. Concurrent performances: Reinforcement interaction and response independence. Journal of the Experimental Analysis of Behavior, 1963a, 6, 253-264.
CATANIA, A. C. Concurrent performances: A baseline for the study of reinforcement magnitude. Journal of the rxperimental Analy sis of Behavior, 1963b, 6, 299-300.

CATANIA, A. C. Concurrent performances: Inhibition of one response by reinforcement of another. Joumal of the Experimental Analy sis of Behavior, 1969, 12, 731-744.

FINDLEY, J. Preference and switching under concurrent scheduling. Journal of the Experimental Analysis of Behavior, 1958, 1. $123-144$.

HERRNSTEIN, R. J. Relative and absolute strength of response as a function of frequency of reinforcement. Journal of the Experimental Analysis of Behavior, 1961, 4, 267.272.

O'BRIEN, F. Sequential contrast effects with human subjects. Journal of the Experimental Analysis of Behavior, 1968, 11, 537-542.

PLISKOFF, S. S., SHULL, R. L., \& GOLLLB, R. $L$. The relation between response rates and reinforcement rates in a multiple schedule. Journal of the Experimental Analysis of Behavior, 1968, 11, 271-284.

PREMACK, D. Reinforcement theory. In Nebraska symposium on motivation. Lincoln: University of Nebraska Press, 1965. Pp. 123-180.

RACHLIN, H., \& BAUM, W. M. Response rate as a function of amount of reinforcement for a signaled concurrent response. Journal of the Experimental Analysis of Behavior, 1969, 12, 11-16.

REYNOLDS, G. S. Behavioral contrast. Journal of the Experimental Analysis of Behavior, $1961 \mathrm{a}, 4,57-71$.

REYNOLDS, G. S. An analysis of interactions in a multiple schedule. Journal of the Experimental Analysis of Behavior, 1961b, 4, 107-17.

REYNOLDS, G. S. Relativity of response rate and reinforcement frequency in a multiple schedule. Joumal of the Experimental Analy sis of Behavior, 1961c, 4, 179-184.

SHIMP, C. F. Optimal behavior in free-operant experiments. Psychological Review, 1969, 76. 97.112.

WILLIAMS, D. R. Classical conditioning and incentive motivation. In W. F. Prokasy (Ed.), Classical conditioning. New York: Appleton-Century-Crofts, 1965 . Pp. 340-357.

\title{
Effects of agroclavine on wheel-turning activity in mice
}

\author{
WELDON L. WITTERS, Ohio University, Athens, Ohio 45701 \\ and \\ C. W. FOLEY, University of Georgia, Athens, Ga. 30601
}

Five groups of mice received $0,30,90,270$, or $810 \mathrm{mg} / \mathrm{kg}$ body weight of agroclavine, a drug chemically similar to LSD. Over 5 consecutive days smaller dosage levels either enhanced or produced little change in wheel-running activity, while higher dosages produced a decrement.

LSD is a well-known hallucinogenic compound derived from ergot alkaloids. Catagnoli \& Tonalo (1966) show that LSD, agroclavine, and elymoclavine are very similar structurally. Agroclavine differs from elymoclavine by lacking a hydroxyl 


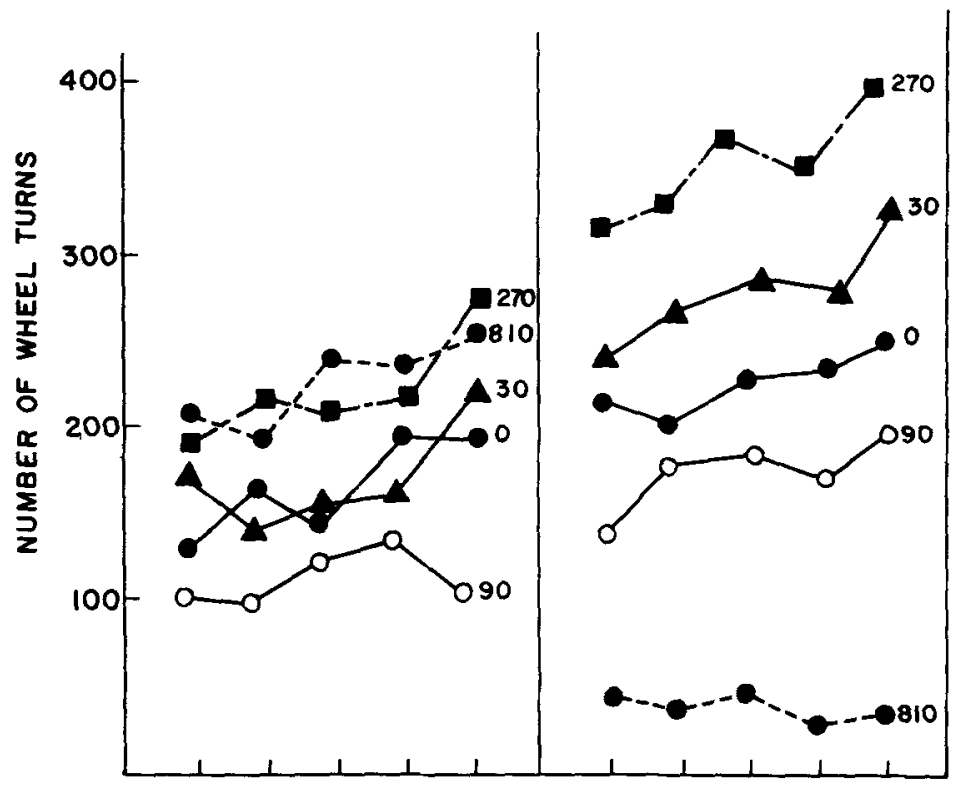

Fig. 1. Mean number of wheel turns for each group during baseline and drug days ( $N=5$ for each group).

group on the No. 8 carbon. Rothlin (1957) reported that these compounds have similar behavioral effects and may produce mydriosis, straub tail effect, spastic paresis, ataxia, excess urination, piloerection, and hyperirritability. Yui \& Takao (1958a, b) found that these compounds produce similar analeptic reactions and EEG effects. Hamilton (1960) and Ray \& Wong (1967) found that these compounds facilitated avoidance learning in rats. Recent studies by Essman (1967) and Slivka, Landis, \& Mountjoy (1967) indicate that larger doses of LSD have a debilitating effect on general activity. The present experiment was designed to explore the relationship between agroclavine dosage level and general activity and to compare the results to those by Harsh, Witters, \& Yaremko (1970) with elymoclavine.

SUBJECTS AND APPARATUS

Twenty-five male Swiss Webster mice, weighing approximately $30 \mathrm{~g}$ each, were maintained on ad lib food and water throughout the experiment. The apparatus consisted of seven Wahman activity wheels that recorded each full turn in either direction.

\section{PROCEDURE}

The Ss were divided randomly into five groups of five $\mathrm{Ss}$ each. To determine basal activity levels, each $S$ was placed in the apparatus for $30 \mathrm{~min}$ each day for 5 consecutive days. Each group was then assigned randomly a dosage level of 0,30 , 90,270 , or $810 \mathrm{mg} / \mathrm{kg}$ body weight. Agroclavine was dissolved in $1.0 \%$ tartaric acid solution and injected intraperitoneally. The 0 group received an injection of the base solution. On each of 5 consecutive days, each $S$ was placed in a cage adjacent to the activity wheel for a 10 -min postinjection period. This was followed by $30 \mathrm{~min}$ in the wheel.

\section{RESULTS}

The dependent variable was the number of full wheel turns recorded for each 30 -min session. Figure 1 illustrates the mean number of wheel turns for each group for all baseline and experimental days. The figure shows the general trend toward increased activity over baseline days was disrupted on the first drug day, with Group 810 showing a decrease in activity, while Groups 30,90 , and 270 increased and Group 0 remained about the same. While changes in activity levels for Groups 30,90 , and 270 were significant, $[t(4)=2.85,2.92$, and 3.11 , respectively, $\mathrm{p}<.05$ for all three], Group 810 had a highly significant change $[t(4)=8.75$, $\mathrm{p}<.001]$.

Analysis of variance of the baseline data revealed that the overall increment in activity over days was significant $[F(r, 80)=11.52, p<.001]$ and that the groups and Groups by Days effects were not significant. Analysis of the drug data indicated a significant dosage effect $[F(r, 80)=5.68, p<.05]$. Duncan's multiple range test indicated that Groups 30 and 90 were not significantly different, but both differed from Group 270 $(\mathrm{p}<.10)$ and Group $0(\mathrm{p}<.01)$ and from Group $810(p<.001)$. Group 0 differed from Group $810(p<.01)$ and Group 270
( $p<.01)$. Group 270 differed from Group $810(\mathrm{p}<.001)$.

\section{DISCUSSION}

These results show clearly the nonmonotonic effect of increasing dosage levels of agroclavine on activity. Smaller doses produced an increment in performance, with the greatest facilitation at the $270-\mathrm{mg} / \mathrm{kg}$ level, while larger doses produced a relative decrement in activity. The possibility that cumulative toxic effects of the drug were, at least in part, responsible for the performance of Group 810 is evidenced by the fact that two of the five mice used in this group died within 4 days after completion of the study. No deaths occurred in the other groups.

The results of this study are similar to those done by Harsh, Witters, \& Yaremko (1970) with elymoclavine if the dose size is disregarded. The amount of agroclavine needed to provide results similar to elymoclavine is much greater. It has been found recently by Yui \& Takeo $(1958 \mathrm{a}, \mathrm{b})$ that elymoclavine is the more potent of the ergot alkaloids, other than LSD. LSD is many times more potent psychogenically than other ergot alkaloids (Appel \& Freedman, 1965).

\section{REFERENCES}

APPEL, J. B., \& D. X. FREEDMAN. The relative potencies of psychotomimetic drugs. Life Sciences, 1965, 4, 2181.

CASTAGNOLI, N., \& TONOLO, A. Ergot alkaloids in submerged culture. International Congress of Microbiology Symposium. Vol. 9. New York: Pergamon Ptess, 1966. Pp. 31-40.

ESSMAN, W. B. Changes in locomotor activity and brain chemistry following LSD-25 administration in mice. Psychological Reports, 1967, 20, 124-126.

HARSH, J., WTTTERS, W. L., \& YAREMKO, R, $M$. Effects of elymoclavine on wheel turning activity in mice. Psychonomic Science, 1970, $18,301.302$.

ROTHLIN, E. Pharmacology of lysergic acid diethylamide and some of its related compounds. Journal of Pharmacy \& Pharmacology, 1957, 9, 569-581.

HAMILTON, C. L. Effects of LSD-25 and amphetamine on a running response in the rat. Archives of General Psychiatry, 1960, 2, 104-109.

SLIVKA, R. M., LANDIS, D., \& MOUNTJOY, P. T. Effect of LSD-25 on activity level of the hooded rat. Psychological Reports, 1967, 20 , 158.

RAY, A. J., \& WONG, S. Effect of elymoclavine on conditioned avoidance. Archives of International Pharmacodynamics, 1967, 166, 253-257.

YUI, T., \& TAKEO, Y. Neuropharmacological studies on a new series of ergot alkaloids: Elymoclavine as a potent analeptic on reserpine sedation. Japanese Journal of Pharmacology, 1958a, 7, 157-161.

YUI, T., \& TAKEO, Y. Neuropharmacological studies on a new series of ergot alkaloids: The effects of elymoclavine on electrocorticogram of rabbits. Japanese Journal of Pharmacology, $1958 b, 7,162-168$. 